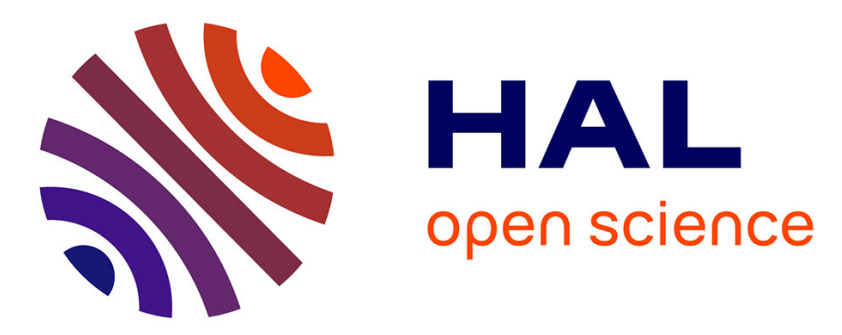

\title{
A methodological proposal to assist scenario-based design in the early stages of innovation projects
}

\author{
Julien Nelson, Stéphanie Buisine, Améziane Aoussat
}

\section{To cite this version:}

Julien Nelson, Stéphanie Buisine, Améziane Aoussat. A methodological proposal to assist scenariobased design in the early stages of innovation projects. Le travail humain, 2012, pp.75, 279-305. hal-00790216

\section{HAL Id: hal-00790216 https://hal.science/hal-00790216}

Submitted on 19 Feb 2013

HAL is a multi-disciplinary open access archive for the deposit and dissemination of scientific research documents, whether they are published or not. The documents may come from teaching and research institutions in France or abroad, or from public or private research centers.
L'archive ouverte pluridisciplinaire HAL, est destinée au dépôt et à la diffusion de documents scientifiques de niveau recherche, publiés ou non, émanant des établissements d'enseignement et de recherche français ou étrangers, des laboratoires publics ou privés. 
THEORIES AND METHODOLOGIES SCENARIO-BASED DESIGN IN INNOVATION PROJECTS

\author{
A METHODOLOGICAL PROPOSAL \\ TO ASSIST SCENARIO-BASED DESIGN \\ IN THE EARLY STAGES OF INNOVATION PROJECTS
}

By Julien NeLson ${ }^{1}$, Stephanie Buisine ${ }^{2}$, AmeZiane Aoussat ${ }^{3}$

RESUME

PROPOSITION METHODOLOGIQUE POUR ASSISTER LA CONCEPTION PAR SCENARII DANS LES ETAPES INITIALES DE PROJETS D'INNOVATION

Les ergonomes sont de plus en plus sollicités pour intervenir dans les phases initiales des projets de conception innovante. Leur contribution s'appuie le plus souvent sur l'analyse d'activités existantes, ou de situations permettant d'appréhender l'activité future des usagers (ex. simulations). Dans les deux cas, on pose les hypothèses que (a) l'énoncé initial du problème de conception permet d'identifier clairement des situations de référence pour décrire l'activité future, et (b) le concept de produit est suffisamment mûr pour permettre la production d'objets intermédiaires (maquettes, prototypes), dont l'usage pourra être analysé. Dans les étapes initiales de projets d'innovation, ces postulats ne sont pas toujours vérifiés. Les ergonomes peuvent alors être appelés dans les étapes idéatives du projet, pour proposer et examiner des concepts de produits et d'usages nouveaux.

Dans cet article, nous évaluons l'apport, dans ce cadre, d'outils empruntés à la résolution créative de problèmes et à la fiabilité industrielle pour générer et analyser des scénarios d'usage. Lors de simulations de réunions de conception, nous avons invité des équipes pluridisciplinaires de concepteurs à anticiper les usages de deux produits innovants : une table interactive et un dispositif de prévention de la noyade infantile. Les participants travaillaient soit librement, soit en utilisant les méthodes du brainwriting et de la matrice de découvertes, pour construire des scénarios. Ils généraient ensuite, suivant une méthode dérivée de l'Analyse des Modes de Défaillance, de leurs Effets et de leur Criticité, des revendications pour la conception. A partir de l'analyse de traces écrites et orales de l'activité et d'un, nous avons évalué la performance créative et le ressenti subjectif des opérateurs. Notre méthodologie originale associe une approche de l'analyse de l'activité répandue dans l'étude des

\footnotetext{
${ }^{1}$ Equipe Ergonomie, CRTD-CNAM, 41 rue Gay-Lussac, 75005 Paris - julien.nelson@cnam.fr :

${ }^{2}$ Arts et Metiers ParisTech, LCPI, 151 bd de l'Hopital, 75013 Paris, France - stephanie.buisine@ensam.eu

${ }^{3}$ Arts et Metiers ParisTech, LCPI, 151 bd de 1'Hopital, 75013 Paris, France-ameziane.aoussat@ensam.eu
} 
activités de conception, avec le cadre théorique de la génération d'idées en groupe, utilisé dans des travaux en psychologie de la créativité.

Comme les autres métiers de la conception représentés (ingénieurs et designers industriels), les ergonomes ont pu générer des idées sur les usages futurs possibles des produits, mais leur expertise leur a permis d'en produire davantage. Les outils proposés montrent un besoin de structurer l'exploration d'usages dans les phases amont du processus. Ils ont permis de meilleures performances chez les concepteurs travaillant sur la table interactive, mais les résultats ont été moins concluants pour le travail sur l'équipement de sécurité. L'AMDEC modifiée pourrait, enfin, permettre de répartir l'interprétation des scénarios sur plusieurs équipes de travail. Ces résultats, enfin, encouragent au développement d'une ergonomie prospective de l'innovation.

MOTS-CLE: Conception innovante, conception de produits, Scénarios d'usage, ergonomie prospective, créativité.

\section{INTRODUCTION}

Ergonomists involved in projects to design innovative products have, in recent years, been subjected to increasing pressure from the stakeholders of user-centred design projects (UCD) to optimize costs, quality and time by reducing the number of iterative cycles for product design and evaluation. In this context, they are increasingly requested to contribute to the early, ideative (i.e. idea-generation) stages of the innovative design process (Kantrovich, 2004; Zeng, Proctor, \& Salvendy, 2010). At this stage, Brangier and Bastien (2006) argue, the classical methods of ergonomics, based on the analysis of existing activities or the simulation of future activities, may reach their limits. This is notably because this approach assumes that ergonomists can always identify clear situations of reference for analysis.

In the first part of this paper, we describe two situations of innovative design where the limitations of this approach are particularly apparent: when working in "technology-push" design projects, and when working on situations that are inaccessible to activity analysis for practical and/or ethical reasons, e.g. when anticipating accident situations to design safety systems. In these instances, it is necessary for designers to generate scenarios of future use. In the second part, we introduce Creative Problem Solving (CPS) as a possible aid for the generation of speculative scenarios of future use, in an effort to address the limitations of the analysis of existing activities, outlined above, in the early stages of innovative design. Although some authors have advocated the use of CPS tools to assist the definition of future use in UCD (Maguire, 2001), no studies have, to our knowledge, focused on assessing the benefits of these methods in this task. Indeed, this task is rarely emphasized in UCD. The standard UCD process model places little emphasis on "anticipating future use", focusing instead on "understanding the context of use" (ISO 13407, 1999). This suggests that the context of use is clearly defined, like the product concept, before the process begins. It is not always the case in innovative design. In the third part of the paper, we describe an experimental protocol to assess the benefits 
of CPS tools, used in conjunction with tools from reliability engineering. Design teams worked on a "brief" - an early and incomplete formulation of a product concept, due to be developed. They produced scenarios describing the future use of two innovative products. In the final section of the paper, we present the results obtained in this experiment, and discuss their implications for future research and practice in ergonomics.

\section{CHALLENGES FOR ERGONOMICS IN INNOVATIVE PRODUCT DESIGN}

\section{II.1 SOME LIMITATIONS OF ACTIVITY ANALYSIS IN THE EARLY STAGES OF INNOVATIVE DESIGN}

Innovation, specifically the introduction of a new good in a market, is viewed as a key aspect of development in a capitalist economy (Schumpeter, 1934). The term "new product development" describes the process whereby a company designs a new product, and launches it onto a market for purchase by consumers (Veryzer \& Borja de Mozota, 2005).

Numerous authors have provided models of the innovative, or creative, design process that leads to the design of new products (Howard et al., 2008). Typically, these models describe the evolution of the product being designed, from the ideational stages, which serve to generate concept ideas in response to a brief, to the end product that is launched onto the market. Between these two points, the product concept is gradually materialized through "Intermediary Objects of Design", or IODs, to support decision-making (Vinck, 2009). A prototype is an example of such an IOD: it allows designers to evaluate design decisions by confronting productions of the design process with representatives of future users in a specific context of use. Yet, the production of such prototypes requires that the product concept be detailed enough to produce an IOD, the use of which can then be analysed.

Currently, the contribution of ergonomics to design, and NPD (New Product Design) in particular, relies most often on the analysis of "real-world activities" and on the simulation of future activities (Daniellou, 1992; Béguin, 2007a). Typically, parallels are drawn between existing reference situations (e.g. the use of an existing product of similar function to the product being designed, or the use of an intermediate object of design) and the projected characteristics of future use. The analysis of the former then allows designers to extrapolate some features of the latter. This approach poses several problems in innovative design. Firstly, it may be difficult to imagine future activities based on the analysis of existing ones. The very reason why one designs a new product is to ensure that it will alter user activity. This has been called the "paradox of design ergonomics" (Theureau \& Pinsky, 1984). Secondly, the notions of "users" and "product use" do not predate the product. They are a product of designer activity (Bardini \& Horvath, 1995; Redström, 2006). Before parallels can be drawn between present and future activities, the product concept must 
be detailed enough for designers to formulate expectations about who the users of the product will be, and what their future activity will be. This is a problem, because the early stages of innovation projects are characterized by great uncertainty. The time between the early explorations of the design brief and the definition of the product concept, is sometimes termed the "fuzzy front-end of innovation" (Reid \& de Brentani, 2004). Ergonomics is often unable to contribute to these stages of the NPD process (Kantrovich, 2004). Robert and Brangier (2009) have pointed this out as a major milestone for the development of the discipline. To us, there are two situations of innovative design where limitations of the traditional approach of ergonomics are especially apparent.

The first situation, as pointed out by Anastassova (2006), is the design of "emerging technologies", which is often motivated by a strong drive toward technological innovation. This implies uncertainty regarding future use, typically in the early stages of the process. For example, a company specialized in an innovative technology may undertake projects to introduce a technological innovation. The primary goal of design is to materialize this innovation; product use is usually a secondary concern, at least in the short term. Project stakeholders typically choose product applications with little prior investigation of user needs and activities. It follows that there is little creativity in the generation of product concepts.

The second situation stems from the fact that once a concept has been generated, it must be validated before the process can continue. Designers achieve this by examining the concept within the "space of variability" of future use (Daniellou, 2004). Some authors (e.g. Mallard, 2005) have stressed that it is never possible to validate the product concept through comprehensive anticipation of future use: there will always be unforeseen situations of use, confronting the product with new challenges. However, in some projects, there is pressure to anticipate future use as precisely as possible before the product is materialized and launched. Adamski and Westrum (2003), in safety systems design, call this requisite imagination - the ability of designers to foresee a wide range of situations without necessarily relying on realworld data, when such data is unavailable, e.g. when dealing with rare accidents.

\section{II.2 USING SCENARIOS TO DEFINE FUTURE USE IN INITIAL STAGES OF INNOVATION PROJECTS}

Carroll (2000) points out that decision-making in design can rely on "scenarios of future use", which he define as "stories about people and their activities". De Sá and Carriço (2008) write: "The generation of scenarios and personas during the design process is an implicitly enormous task, including an endless variety of combinations and presenting itself as a difficult and demanding task to designers. Still, given the impossibility of visiting and observing all the possible usage settings and contexts, this scenario generation process is many times mandatory and indispensable during early design stages". Hanington (2003) describes two types of scenarios: speculative scenarios, which "may be used to test ideas of product engagement and use" during the early work on the design brief; and actual scenarios, which "may involve actual product testing", in the later, evaluative stages. Concept generation and validation in 
innovative design are, then, both dependent on the production and on the critical examination of scenarios.

One way to assist design is therefore to help designers generate speculative scenarios of future use in the fuzzy front-end of the innovation process, particularly in the situations quoted above as exemplifying the limitations of traditional methods of design ergonomics. At this stage, speculative scenarios of use are expected to allow designers to define expectations related to future use. The more designers are able to generate and explore scenarios of future use, the better they will be able to specify and select innovative product concepts. Only once this is done can more traditional methods of activity analysis and simulation-based ergonomics be used in the process.

Designers must, therefore, be able to generate speculative scenarios of use and examine them to $(a)$ assess the benefits and drawbacks of a particular concept with respect to future use, and to $(b)$ pilot future design projects. Carroll and Rosson (1992) have termed this process claims analysis. Based on scenarios, designers generate positive claims (i.e. related to advantages) and negative claims (i.e. related to drawbacks) regarding future use. This specifies which characteristics of design should be preserved, and which should be eliminated. In the initial stages, it may also help stakeholders decide which projects are worth approving for further development, and which must be abandoned. This, according to Robert and Brangier (2009), is a key function of "prospective ergonomics".

The form that scenarios should take is a long-standing issue (Carroll, 2000). There is a consensus that scenarios are "stories of use", but there are no real guidelines as to how detailed a scenario should be, in order to be relevant to design. In the ideative stages of design, one can argue that the goal of scenarios is to raise interest in specific issues and concepts of use, so these can be explored in subsequent stages. The only requirement is that designers should be able to formalize "propositions" regarding a product concept. This term, introduced by Hatchuel and Weil (1999), refers to statements which designers hold to be true regarding the product - specifically, for us, concerning its future use. Such propositions can trigger:

- Expansions of a design concept: decision-making allows designers to specify the product concept and define expected future use. This allows the design process to move forward;

- Expansions of knowledge: For example, early discussions might focus on establishing "comfort" as an important issue regarding a specific product concept. Subsequent investigations and discussions would then allow designers to clarify exactly what is meant by "comfort in use" for a specific project or product concept.

In this paper, we define scenarios as ideas regarding future situations of use, allowing designers to formulate claims related to the possible advantages and drawbacks of a particular product concept in use. In the "fuzzy front-end" of NPD, a scenario need not satisfy all of Carroll's (2000) criteria as to its contents - to have a well-defined setting, agents, goals, and a plot - just as long as designers can make claims regarding future product use. These claims can, if needed, be investigated in later stages by more traditional methods of ergonomics. Activity analysis, for 
example, is a way for designers to generate and refine claims, but it requires for the product concept to be clearly defined. The key questions, in terms of research, are these: how can one assist generation and exploration of scenarios of future use, in the early stages of innovation processes when the concept is ill-defined with respect to future use? How should these scenarios guide the later stages of design?

\section{II.3 “USE FRAMES” AS AN INTERMEDIATE STEP TO BUILDING SPECULATIVE SCENARIOS OF USE.}

It has been said that the contribution of ergonomics to design relies on characterizing a "space of variability" of human activity (Daniellou, 2004). In product design, which our work focuses on, some have contended that this variability is greater than in, for example, work system design (Valentin, Lancry \& Lemarchand, 2010). Since the goal of innovation is to allow a wide audience of users to encounter a new product, this greater variability impacts both the identity of users, and possible contexts of use.

To cope with this variability, one suggestion has been to structure ergonomic interventions by identifying "characteristic situations of use" of the system to be designed (Jeffroy, 1987; Daniellou, 1992). The practitioner must first describe the general "frame" of the intervention. In work system design, this implies identifying, within an existing or projected system, which operators are involved, what their tasks are, which tools are used, etc. (Daniellou, 1985). Clearly, this approach is not valid in the "fuzzy front-end" of NPD, where some of these elements may be ill-defined or unknown. Such situations, as stated above, may rely on analyzing not real-world situations, but speculative scenarios. Yet the need to structure the exploration of variability in future use, we contend, is still present.

De Sá and Carriço (2008) propose a framework for scenario generation, based on combining variables related, for example, to locations and settings (e.g. lighting or noise conditions), to devices and their usage (e.g. interaction modes), etc. Combining these variables, each within a specific set of values, allows designers to generate frames for use. In turn, each frame may serve as an intermediate structure to produce several scenarios. Although the authors provide examples of scenarios generated by using this framework, they fail to specify how it can be implemented in design projects. Viewing "use frames" as intermediate structures for scenario generation in the early stages of NPD, two questions arise. First, how should ideas be generated with respect to the various elements of the use frame? Second, how can one decide which combinations of use frame elements should be explored, and subsequently, generate scenarios? Our work aims to provide tools in response to both these questions. For both, there is an element of anticipation of future use. The section below describes some limitations of anticipatory reasoning in designers. We then go on to show how the components of our method are expected to address these limitations and improve performance of design teams in this aspect of their work. 


\section{DESIGN AS ANTICIPATION OF FUTURE USE}

\section{III.1 ANTICIPATION OF FUTURE USE IS CONSTRAINED AND GUIDED BY DESIGNERS' KNOWLEDGE}

Cognitive ergonomics has described design as implying the progressive specification of an artefact (the product). This is based on the generation, transformation and evaluation of mental representations from initial requirements (Visser, 2009). Visser also notes that the generation of representations relies on external resources - such as the design brief, which embodies the initial requirements - as well as internal resources, notably knowledge stored in designers' long-term memory. This has led Béguin (2007b), for example, to argue that the end product of design "crystallizes a knowledge, a representation or a model" of users and their activity (emphasis in original).

Another way to see this is to say that designers' knowledge constrains their representations of future use. Indeed, as we have pointed out above, the user - as well as his/her tasks - are first and foremost, constructions made by designers, based on available knowledge, to further the design process. Typically, for example, designers anticipate user needs and activities by relying "on personal experience, (...) replacing [their] professional hat with that of the layman's" (Akrich, 1995). The perils of designers "designing for themselves", are usually used as an argument to involve users early in the design process. However, this is only possible if the identity of users is clearly defined.

This reliance of designers on themselves as representatives of typical users, termed "I-methodology" by Akrich, can be seen as an example of the "foresight bias" (MacKay \& McKiernan, 2004). According to these authors, scenario building rests on " $a$ combination of past experiences, cultural mythologies, routinised behavior, religion, ideology, the media, entertainment and so on". The result is "an overconfident and over-simplified view of the future". This is a direct threat to innovation, which is defined by product concepts evolving, and products finding new identities throughout design and use (Hatchuel \& Weil, 1999). Creative Problem Solving (CPS) tools are typically used to assist these "conceptual expansions". We describe below how these methods have so far been used as a tool for UCD. We then argue that CPS methods may be used to help designers anticipate and negotiate future use in the early stages of innovative design.

\section{III.2 CREATIVE PROBLEM SOLVING TOOLS AS MEANS TO ASSIST THE CONSTRUCTION OF SCENARIOS OF FUTURE USE}

Creativity may be defined as "the ability to generate an idea, a solution or a production that is both new and suited to the situation - and, in some cases, considered as being of some usefulness or value" (Bonnardel, 2009, our translation). It is a cornerstone of innovation, and several authors have attempted to model it, both as a manifestation of human activity and as an element of the design process (e.g. 
Boden, 2004; Howard et al., 2008). From an industrial point of view, the goal of these efforts is often to help ideation in the early stages of design, yielding greater control over the innovative design process.

Creative Problem Solving (CPS) is a model of the creative process developed by Osborn (1957) to train individuals to think more creatively. It is geared towards improving performance in idea production. Brainstorming is the most famous contribution in Osborn's work. It is based on four simple rules: 1) criticism is ruled out, 2) freewheeling is encouraged, 3) quantity is wanted, and 4) combination and improvement are sought. CPS has been mentioned as a possible tool to assist UCD (e.g. Maguire, 2001). Yet, we feel that the potential of these methods for UCD has not been fully explored, for two main reasons.

Firstly, CPS has been used mainly to answer questions only once designers were past the "fuzzy front-end of innovation". For example, it has served as a tool to involve users in a participatory design process, specifically to elicit user requirements in a more comprehensive manner, e.g. in the Group Elicitation Method (Boy, 1997). It has also been used by designers operating in a UCD process, at a stage where the users and context were identified: Oulasvirta et al. (2003) have used brainstorming "in the wild" to analyse user needs and generate creative product concepts to address them. In both these cases, the identity of the future users and, to some extent, the context of use, are identified before to the CPS tools are used. Few authors, in contrast, have used these tools to generate ideas relative to the basic "building blocks" of use frames, to construct use in the ideative stages of the process (see Hackos \& Redish, 1998 for a notable exception). CPS methods are expected to allow expansions of designer knowledge regarding future use and/or product concepts in UCD.

Secondly, Osborn's claims regarding the effectiveness of brainstorming have prompted research on the cognitive and social factors which impact group performance in idea generation tasks (Paulus, 2000; Stroebe, Nijstad, \& Rietzschel, 2010). Unexpected - but consistently observed - experimental results, such as productivity loss in individuals interacting in groups $v s$. those working alone, led to new tools being derived from brainstorming to circumvent its limitations, such as brainwriting (Paulus \& Yang, 2000). These studies also led to social-cognitive models of idea generation in groups. These models aimed to verify other claims, made by Osborn, such as the importance of stimulation through confrontation of multiple points of view in a group (Nijstad \& Stroebe, 2006; de Dreu, Nijstad, \& van Knippenberg, 2008). Despite the fruitfulness of this research, group productivity in idea generation is often assessed only in fairly abstract tasks. With the possible exception of the "alternate uses task", which instructs participants to imagine as many uses as possible to an existing artefact (e.g. a brick, a paperclip, etc.), CPS tools have not been experimentally assessed in their ability to assist designers in the task of exploring future use - and never in the early stages of the innovation process.

The work presented in this paper aims to fill this theoretical and methodological gap. In the next section, we describe an experimental protocol that aims to assess the effects of CPS methods on idea production regarding scenarios of future use, as defined above. 


\section{METHOD}

\section{IV.1 SCENARIO GENERATION AND EXPLORATION: AN IDEATIONAL APPROACH AND HYPOTHESES}

Integrating ergonomics in the ideational stages of the innovative design process changes the object of ergonomists' activity. Instead of focusing on "real-world situations of use", it focuses on potential situations, which exist only as ideas. This is especially necessary when the concept formulation in the design brief does not allow ergonomists to identify clear references for ergonomic analysis to apprehend future use. However, idea generation is only one part of the problem. The creative design process includes alternating divergent (idea generation) and convergent (idea selection) stages (Cropley, 2006). As the project advances, this process focuses on increasingly specific design features.

We posit that the variability of human activity makes it even more necessary for designers in the ideative stages of innovation to rely on an intermediate step between the design brief on the one hand, and generating scenarios of future use on the other. In section II.2, we proposed the construction of "use frames" as this intermediate step. Our process model therefore comprises two cycles of divergence-convergence. Figure 1 shows overall the structure of the innovation process following this assumption. As noted by Brangier and Robert (2010), prospective ergonomics - that our toolbox focuses on - precedes the more classical preventive ergonomics (which follows concept validation) and corrective ergonomics (which follows product launch).

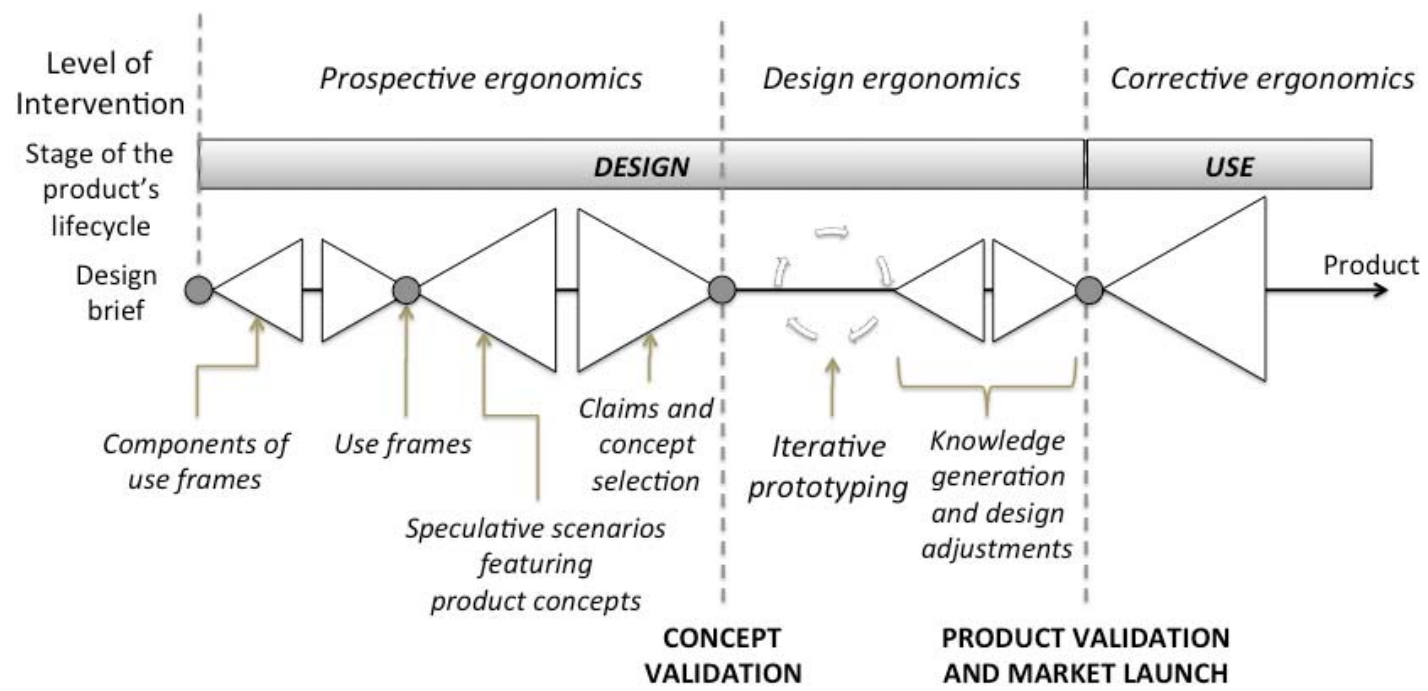

Figure 1: Overview of the innovation design process integrating prospective, preventive and corrective ergonomics

Figure 1: Un apercu du processus de conception innovante proposé, integrant l'ergonomie prospective, l'ergonomie de conception, et l'ergonomie corrective 
If one likens the contribution of ergonomists to the ideative stage of NPD to an idea generation task, the question becomes: how can one assess a design team's performance, and more specifically the effects of the tools proposed? To do this, we rely on the paradigm of group idea generation. Following Osborn's (1957) original work, a basic criterion of performance assessment is ideational fluency: the number of answers produced in response to a specific problem. Other criteria have also been devised to assess creativity (Plucker \& Makel, 2010), including measuring the unique character of responses (originality), or the number or uniqueness of response categories (flexibility), In this paper, we focus on fluency, which is used even today as a primary criterion of creative performance.

We have argued, in prior work, that the scenarios constructed in the early stages of the innovation design process, drive this process based on one main question: do these scenarios describe situations which are desirable or undesirable from the point of view of stakeholders? (Nelson, Buisine, \& Aoussat, 2009). In this view, likening the anticipation of future use to "chain-generating ideas" is not enough; one must also consider, amongst other things, how designers perceive their performance with respect to the goal of anticipating the future use of a product. The concept of perceived self-efficacy was developed to understand the factors underlying people's beliefs regarding their own capability to produce certain effects in their activity (Bandura, 1997). Here, the "intended effect" is to help designers make relevant design decisions based on claims generated in the ideative stages of the innovation process. This concept of self-efficacy is important to our work, since it leads designers to advance in the design process, based on assumptions on future use.

Returning to our process model (Figure 1), ideas are produced at both steps of creative divergence, but not with the same degree of precision. First, participants produce ideas regarding elementary components of the future context of use. These are then combined to formulate frames. Second, based on these frames, they generate scenarios of future use. As stated above, these scenarios need not have all the components of a detailed story. They can be very short, merely describing an interesting setting in just a few words. The point is that they can be analysed in terms of positive and negative claims regarding the product's future use.

From there, four hypotheses can be made regarding the effects of CPS on the construction and exploration of scenarios of future use:

H1.CPS methods are expected to improve ideational fluency in the stages preceding concept validation in Figure 1, both regarding the number of elements of use frames generated, and the number of scenarios produced from these frames;

H2.Equity, in Osborn's paradigm, can be seen as a desirable characteristic of group idea generation (Buisine, 2010). When generating ideas regarding future use, however, ergonomists are expected to be more fluent than other design professionals (e.g. industrial designers or engineers). Indeed, through professional experience, ergonomists collect data and information regarding a wide variety of situations of human activity, which may lead them to construct a "library of situations" to reuse their knowledge in future projects (Daniellou, 2004). This library then becomes a resource for idea generation; 
H3.CPS methods are expected to improve participants' perception of their selfefficacy when anticipating future use;

H4.As CPS is geared towards fluency, this raises the issue of organizing creative production (scenarios of future use), to help designers generate claims and prioritize design at the end of the concept validation stage. To prevent the team from being swamped in a "sea of ideas", one solution might be to allocate creative production to several different teams. However, designers involved in the creative production process are expected to generate claims related to hazards and opportunities in future use more efficiently than "newcomers" who are strangers to this production.

\section{IV.2 CHOOSING RELEVANT METHODS FOR CPS}

Our method for scenario generation and analysis comprises two stages (Figure 2).

In the first stage, participants used a brainwriting procedure to generate ideas related to elements of the use frame, then combined these ideas using morphological analysis to generate prospective scenarios of future use. This therefore corresponds to 1.5 cycles in Figure 1: generating ideas related to use frame elements (divergence), combining them within a morphological analysis matrix (convergence) and generating ideas related to scenarios of future use (divergence). Our reasons for choosing these methods are specified below.

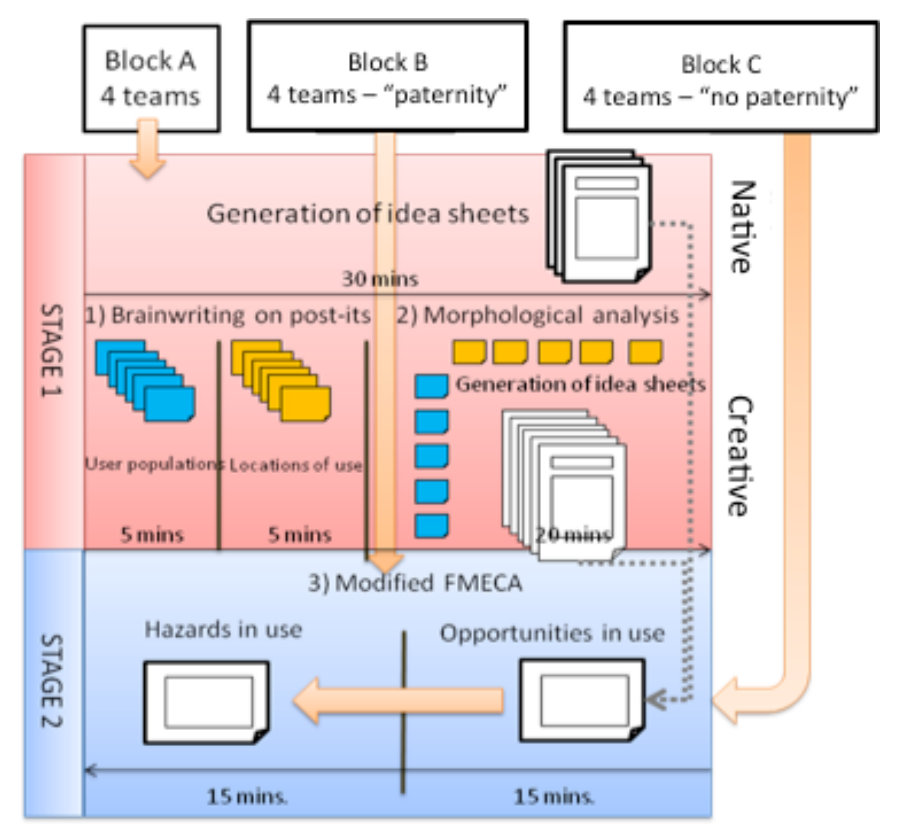

Figure 2: Overview of the experimental protocol

Figure 2 : Schéma du protocole experimental

Brainwriting is expected to improve fluency with respect to Osborn's standard brainstorming rules, for numerous reasons (Heslin, 2009): it prevents production blocking by forcing group members to communicate in written form, using different- 
coloured inks. This reduces the risks related to sharing ideas in a turn-based medium (e.g. forgetting one's ideas, losing patience). It also reduces "social loafing" (i.e. the tendency for some members to underperform in a group) since participants are likely to feel more accountable for their performance if idea authorship is easy to trace.

Morphological analysis is a method that involves combining ideas to generate new outcomes. Possible values for two variables in the problem space (e.g. design issues vs. possible concepts of solutions) are plotted in the rows and columns of a matrix. Each cell of the matrix, at the intersection of row $a$ and column $b$, contains ideas generated by designers and featuring the corresponding combination of variables (e.g. the particular benefits of concept $x$ with respect to issue $y$. It is a common tool in prospective analysis, and allows foresight to be based upon systematic evaluation of future contexts (Voros, 2009). However, which criteria should one use for such evaluation? We chose the criterion of designers' subjective appreciation of ideas regarding components of the use frame (users, locations, etc.), as being a priori interesting to explore, to conduct morphological analysis. The participants chose five interesting locations and five interesting user populations to construct a 5-by-5 matrix. Scenarios produced from this matrix serve as IODs, either to promote interest in specific product concepts and contexts of use, or to dismiss them from further investigation.

In the second stage, participants reprised the creative production from stage 1, and assessed it using modified FMECA tables. FMECA is a common method in engineering, which encourages a componential and inductive approach to risk analysis. The elementary components of the system are examined sequentially. Inductive reasoning allows the analyst to diverge and envision a) multiple possible failures of the technical components, b) multiple possible causes for these failures, and c) multiple possible strategies to prevent them. This tool therefore presents an interesting potential for multiple levels of creative divergence; but it is not fully suited to the characteristics of the scenario-based design process (Carroll \& Rosson, 1992). Indeed, assessment of scenarios is based on negative, but also positive, claims. It seemed necessary to take into account this aspect of scenario-based design by allowing participants to consider not just the hazards, but also the opportunities that lay in each scenario.

\section{IV.3 PARTICIPANTS}

Forty-eight people (16 men and 32 women) were asked to take part in simulations of exploratory meetings taking place in the early stages of projects of innovative design. The goal of these meetings was specifically to discuss and anticipate future use of the products that were to be designed. To account for the various points of view expressed in a multidisciplinary design team, participants were selected depending on their background. Thirty-six participants were design professionals (12 engineers, 12 ergonomists, and 12 industrial designers). Additionally, twelve subjects, said to be "naïve", had no experience or training in design. They were recruited to stand in as representatives of future users, in this stage 
of the process where the definition of the future user was incomplete. We recruited non-designers in an effort to avoid designers acting as "reflective users" (Bardini \& Horvath, 1995). Participants were divided into twelve teams of four people, each team comprising one subject from each of the four backgrounds.

As seen in Figure 2, participants were divided into three blocks of four teams, noted A, B and C. Participants from block A only took part in stage 1 of the experiment, not in stage 2 . Those from block B took part in both stages, reprising in stage 2 their creative production from stage 1, i.e. post-its and idea-sheets. Those from block $\mathrm{C}$ took part only in stage 2: each team from block $\mathrm{C}$ used the creative production of one of the teams from block $\mathrm{B}$. Comparing the performances of blocks $\mathrm{B}$ and $\mathrm{C}$ in stage 2 allowed us to verify the paternity $(\mathrm{H} 4)$ hypothesis.

\section{IV.4 MATERIALS}

The experiment took place in a meeting room in our laboratory. Each team was provided with two design briefs. Each brief described the intended attributes of an innovative product, which the participants were asked to work on. It also included several visual IODs. In order to account for the two distinct situations in innovative design which pose problems for activity analysis - concept generation and concept validation (see section II.1) - teams worked on two different projects. The goals of these projects were, respectively, to design:

a. An inflatable necklace to prevent the drowning of infants (Nelson, Buisine, Aoussat, \& Duchamp, 2009), named Little Mermaid. The goal of the meeting was to generate scenarios of use for this product in order to validate and possibly expand the product concept;

b. An interactive tabletop interface, supporting multi-touch and multi-user recognition, named Digitable (Buisine, Besacier, Aoussat, \& Vernier, 2012). The goal of this meeting was to envision applications for this innovative technology, to support collaborative activities.

Depending on the goal of the session, the visual IODs provided were not the same. In project Little Mermaid, where the product concept was clearly defined, some of the design roughs generated in the project were provided. In project Digitable, where the concept was more open to further specification, the objects used were pictures of similar, existing, Human-Computer Interfaces. The pictures were intended to be "use-neutral": they allowed designers to see users interacting with a generic tabletop interface, but gave no clues regarding what tasks the users carried out on the interface, so as not to constrain idea generation.

Materials provided to the participants were as follows:

- For the brainwriting task, pads of post-it notes to record ideas regarding future users and locations of future use;

- For morphological analysis, the post-its produced during brainwriting and a pad of blank idea sheets. These sheets allowed participants to describe scenarios of future use in whatever way they preferred (e.g. using text, a storyboard, etc.); 
- For the modified FMECA task, the idea sheets generated during stage 1, as well as a pad of tables to identify hazardous uses, and one to identify interesting uses. Both these tables included one column to note what idea sheet they were referring to, one column to specify their claim regarding use, and one to grade the claim on a 5-point Likert scale (1=not very dangerous / interesting, 5= very dangerous / interesting).

Participants openly discussing future use were only provided with some blank idea sheets to record their ideas. Throughout the session, participants from each background wrote in different-coloured ink to allow us to trace the source of each written production.

Although some participants were familiar with the three tasks, carrying them out to define possibilities of future use is by no means a standard part of UCD. These tools are more typically used to solve problems of a technical nature, or to generate ideas regarding product concepts, but not regarding product use.

\section{IV.5 PROCEDURE}

Stage 1: Participants were asked to "anticipate as many uses as possible" for the product they were working on, working as a team and using the sheets provided to record their ideas. They were also instructed not to restrict their exploration to situations where "everything went well", but to also include situations that presented a hazard to the user, product, society, etc. Based on the hypotheses presented in section IV.1, the following independent variables were manipulated following a $2 * 2$ design:

- Condition: creative (using the CPS methods described in section IV.2) or native (open generation of scenarios of future use, without these tools);

- Project type: Digitable (concept generation) or Little Mermaid (concept validation).

Teams worked successively on both conditions. A counterbalanced design was used to control effects of condition order and project type. In both conditions, the time limit for task completion was 30 minutes. Additionally, the background variable (engineer, ergonomist, industrial designer, naïve subjects) was recorded to verify the second hypothesis.

In the native condition, participants were given no other instructions.

In the creative condition, participants were provided with the CPS materials described in section IV.4. The rules of brainwriting were then read out loud. These include Osborn's four original rules of brainstorming (Criticism is ruled out: Freewheeling is encouraged; Quantity is wanted; Combination and improvement are sought). In addition, participants were invited to write their answers to the questions in silence, on post-it notes. After writing down an idea, participants were asked to put the pad of notes back on the table, and to take another pad. They removed the used note from that pad, and stuck it at the centre of the table in view of other participants. Five pads were used in total, allowing circulation of ideas between participants. This procedure is adapted from Paulus and Yang (2000). The following questions were 
asked: 1) "Who might the future users of this product be?" Followed by 2) "Where might this product be used?" The time allocated for answering each question was 5 minutes. Participants were then requested to select, for each question, the five answers they felt were most interesting. They used the corresponding post-its to construct a 5-by-5 matrix for morphological analysis. Finally, they used the idea sheets to record their ideas regarding scenarios, using the matrix as a guide. The time allocated to filling in this matrix was 20 minutes.

Stage 2: Participants were provided with the creative output of one of the teams from stage 1 (post-it notes and idea sheets) and were asked to fill the tables for hazard and opportunity analysis. The issue here was not only to verify the relevance of these tables to help generate and grade claims regarding future use; we also wished to verify whether participants with no paternity over the creative production could do so as fluently as the participants who had generated this output themselves. Therefore, the following independent variables were manipulated following a $2 * 2$ design:

- Paternity of the creative production (2): yes (teams from block B) or no (teams from block C);

- Project type (2): Digitable (concept generation) or Little Mermaid (concept validation).

As in stage 1, the background variable was also recorded.

At the end of each condition in stage 1, and at the end of stage 2, participants filled in a questionnaire to assess various aspects of perceived self-efficacy. The questionnaire was constructed following the guidelines proposed by Bandura (2006).

\section{IV.6 DATA COLLECTION AND ANALYSIS}

All written traces produced during the meetings were collected. Participants' activity was video-recorded with prior consent. All verbal utterances were transcribed verbatim using the Transcriber software program. Redundancies between oral and written creative production were filtered out to clarify the authorship of the various ideas produced. Indeed, in many sessions, teams appointed a "scribe" to write down the scenario ideas that emerged in the conversation, a) when filling in the morphological analysis matrix in stage 1 , and $b$ ) when using the modified FMECA tables in stage 2 . In both cases, authorship was given to the person who uttered the idea orally first, not to the scribe.

Verbal production was coded as follows. Each block of text and/or sketches related to a situation of future use was counted as a scenario, regardless of how well defined it was. In each scenario, we isolated all oral mentions to three elements of the use frame: populations of future users, future locations of use, and future user activities. This yielded a total of four dependent variables (DVs) for ideational fluency:

- The number of ideas related to scenarios of use;

- The number of ideas related to users;

- The number of ideas related to locations of future use;

- The number of ideas related to user activities. 
Similarly, performance in the use of the modified FMECA tables from stage 2 was assessed using four DVs:

- The number of items generated in the hazards table;

- The number of items generated in the opportunities table;

- The sum of scores attributed to the items in the hazard table;

- The sum of scores attributed to the items in the opportunity table.

Finally, perceived self-efficacy related to the participants' work was assessed through eight DVs, graded 1 to 100: perceived ability to anticipate future use; perceived ability to assist designers working on the project in future; perceived ability to design a safe product; perceived ability to design an interesting product; ease in carrying out the anticipation tasks; ease in applying the tools provided; overall usefulness of group work; and perceived conviviality of group work.

\section{RESULTS}

Tables 1 and 2 below provide an overview of the data obtained in stages 1 and 2 of the experiment.

\begin{tabular}{|cl|cccc|}
\hline & $\begin{array}{c}\text { \# ideas } \\
\text { (scenarios) }\end{array}$ & $\begin{array}{c}\text { \# ideas } \\
\text { (locations) }\end{array}$ & $\begin{array}{c}\text { \# ideas } \\
\text { (users) }\end{array}$ & $\begin{array}{c}\text { \# ideas } \\
\text { (activities) }\end{array}$ \\
\hline \multirow{2}{*}{ Condition } & $5.2(3.9)$ & $7.1(3.8)$ & $6.9(3.3)$ & $7.2(6.3)$ \\
& Creative & $5.4(5.5)$ & $5.0(5.9)$ & $5.2(6.2)$ & $8.1(11.1)$ \\
\hline \multirow{2}{*}{ Project type } & Digitable & $6.5(5.5)$ & $6.4(5.3)$ & $6.2(4.7)$ & $10.5(11.0)$ \\
& Little Mermaid & $4.1(3.6)$ & $5.6(4.8)$ & $5.8(5.3)$ & $4.8(5.1)$ \\
\hline \multirow{3}{*}{ Professional } & Designer & $4.9(4.5)$ & $4.5(3.9)$ & $6.4(6.6)$ & $6.9(10.3)$ \\
Background & Ergonomist & $8.2(5.5)$ & $9.9(6.0)$ & $7.6(5.4)$ & $13.6(10.9)$ \\
& Engineer & $5.4(4.5)$ & $6.1(4.5)$ & $5.8(4.0)$ & $6.5(6.3)$ \\
& Nä̈ve & $2.9(2.7)$ & $3.6(3.2)$ & $4.3(3.4)$ & $3.7(4.1)$ \\
\hline \multicolumn{2}{r|}{ Overall } & $5.3(4.7)$ & $6.0(5.0)$ & $6.0(5.0)$ & $7.7(9.0)$ \\
\hline
\end{tabular}

Table 1: Mean values for fluency DVs in part 1 (SDs in brackets)

Tableau 1: Moyennes des VD de fluence dans la partie 1 (écarts-type entre parenthèses).

\begin{tabular}{|cc|c|c|c|c|}
\hline & $\begin{array}{c}\text { \# items } \\
\text { (hazards) }\end{array}$ & $\begin{array}{c}\text { \# items } \\
\text { (opportunities) }\end{array}$ & $\begin{array}{c}\text { Total score } \\
\text { (hazards) }\end{array}$ & $\begin{array}{c}\text { Total score } \\
\text { (opportunities) }\end{array}$ \\
\hline \multirow{2}{*}{ Paternity } & Yes & $4.0(2.5)$ & $3.0(3.0)$ & $14.9(10.8)$ & $12.4(13.7)$ \\
& No & $2.6(2.3)$ & $2.7(2.2)$ & $8.8(7.7)$ & $9.1(7.8)$ \\
\hline \multirow{2}{*}{ Project type } & Digitable & $2.7(2.0)$ & $2.2(2.5)$ & $8.9(7.1)$ & $9.2(11.9)$ \\
& Little Mermaid & $3.9(2.8)$ & $3.4(2.6)$ & $14.8(11.3)$ & $12.2(10.5)$ \\
\multirow{2}{*}{ Professional } & Designer & $4.1(2.4)$ & $3.1(1.5)$ & $14.7(9.8)$ & $9.6(3.7)$ \\
Background & Ergonomist & $4.5(2.9)$ & $4.6(3.7)$ & $15.2(10.6)$ & $19.4(17.2)$ \\
& Engineer & $3.1(2.4)$ & $2.4(2.3)$ & $12.0(10.0)$ & $9.1(8.7)$ \\
& Nä̈ve & $1.5(1.4)$ & $1.2(1.5)$ & $5.5(6.4)$ & $4.7(5.7)$ \\
\hline
\end{tabular}

Table 2: Mean values for hazard/interest DVs in part 2 (SDs in brackets)

Tableau 2: Moyennes des VD sur les usages intéressants/dangereux dans la partie 2 (écartstype entre parenthèses). 


\section{V.1 EFFECTS OF THE CPS METHODS ON FLUENCY REGARDING FUTURE USE}

The creative condition was found to have no significant effect on fluency in generating ideas for scenarios of use, user populations, and user activities. However, we noted a main effect of the condition, on the fluency of ideas concerning locations of use: participants in the creative condition produced significantly more ideas than those in the native condition $\left(\mathrm{F}_{(1 / 48)}=3.98, \mathrm{p}=0.052\right)$. Furthermore, an interaction was found between condition and project type $\left(\mathrm{F}_{(1 / 48)}=8, \mathrm{p}=0.007\right)$ : participants were slightly more fluent when working in the native condition on the Little Mermaid project, and when working in the creative condition on the Digitable project.

These results partially confirm H1. In our protocol, CPS in the first divergent stage (i.e. the brainwriting task) served as a preliminary stage, and allowed subjects to freely generate ideas concerning elementary components of use frames. This did not translate to subjects producing significantly more scenarios. But this observation can be partly explained, by the fact that none of the teams had enough time to fill all the cells of the morphological analysis matrix within the allotted time of 20 minutes. One should also point out that participants were unable to capitalize on their entire production, since it was immediately followed by a stage of convergence (i.e. selecting interesting ideas to construct the matrix).

\section{V.2 EFFECTS OF PROFESSIONAL BACKGROUND ON IDEATIONAL FLUENCY}

Stage 1: ANOVA showed a main effect of the background on the number of ideas produced regarding scenarios $\left(\mathrm{F}_{(3 / 48)}=4.19, \mathrm{p}=0.01\right)$. Ergonomists were found to generate significantly more scenario ideas, than product designers $(p=0.033)$ and naïve subjects $(\mathrm{p}=0.001)$. Other pairwise comparisons indicated no other significant effects.

For the various elements of use frames (i.e. locations, users, and activities), several main effects of participant background on fluency were identified. First, it was found to exert a main effect on the number of ideas produced for future locations of use $\left(\mathrm{F}_{(3 / 48)}=6.93, \mathrm{p}=0.001\right)$. Pairwise comparisons showed ergonomists to produce significantly more ideas than participants from any of the three other backgrounds $(p<0.013)$. Other pairwise comparisons showed no significant effects. Second, a main effect of professional background on ideational fluency was found regarding the future activities of users $\left(\mathrm{F}_{(3 / 48)}=4.33, \mathrm{p}=0.009\right)$. Again, ergonomists were found to generate more ideas than any of the other profiles $(\mathrm{p}<0.023)$. Other pairwise comparisons showed no other significant effects. However, unlike the results obtained for fluency in scenarios, locations and activities, no significant effects of participant background were observed on the fluency related to populations of future users.

Stage 2: ANOVA showed a main effect of the professional background on the number of claims related to hazards in future use $\left(F_{(3 / 16)}=2.77, p=0.075\right)$. Naïve subjects made less claims than ergonomists $(\mathrm{p}=0.018)$ and product designers $(\mathrm{p}=0.035)$. No other significant effects were detected. In particular, this finding was not replicated when analysing claims related to opportunities in future use. 
These results verify $\mathrm{H} 2$, confirming the superior ideational fluency of ergonomists when defining use frames and scenarios for design. However, our last point suggests that when assessing ideas (generated using CPS tools), particularly in terms of the opportunities that lay in future use, participants debated with greater equity.

\section{V.3 EFFECT OF CPS METHODS ON SUBJECTIVE EXPERIENCE OF ANTICIPATORY WORK}

ANOVA was also carried out on each of the dependent variables related to subjective experience, using the Condition as a within-group factor and Project type as a between-group factor. The condition was found to exert a significant effect on the perceived ease of use of the tools proposed $\left(\mathrm{F}_{(1 / 30)}=4.03, \mathrm{p}=0.054\right)$. Participants found the toolset proposed in the creative condition - brainwriting and morphological analysis - easier to use than the open generation of scenarios in the native condition. No main effects of the CPS methods were identified for any of the other variables. However, we observed a main effect of the project type on the perceived ease of the anticipation task: subjects found it easier to anticipate future use, when defining future applications in the Digitable project, than when validating the "inflatable necklace" concept for safety equipment, in the Little Mermaid project.

Interestingly, although no further main effects were observed, the condition and project type variables were found to interact, on participants' perceived ability to "design an interesting product". When working on the Mermaid project, they felt they would be more likely to design an interesting concept for safety equipment if they used the CPS methods. But when working on the Digitable project, they felt that open exploration (i.e. in the native condition) would yield more interesting results.

These results partially confirm H3. They provide evidence of participants' need for structure when anticipating future use in the early stages of the design process. They also suggest that the modified FMECA tables have the potential to diversify the criteria designers use to assess scenarios of future use. The "inflatable necklace" concept was clearly geared towards safety; yet participants using CPS felt they had been able to think of this product following other lines, to design not just a "safe" product, but a more "interesting" one as well.

\section{V.4 EFFECTS OF THE PATERNITY OF CREATIVE PRODUCTION ON THE GENERATION OF CLAIMS RELATED TO FUTURE USE}

ANOVA was performed on the four DVs used in stage 2 (number of items in the hazard/opportunity tables, and total hazard/opportunity scores). Concerning hazard claims, no effects of the project or paternity variables were found on fluency. However, participants who had paternity of the creative production graded claims related to hazards in use significantly higher than participants who did not. Hazard claims were also graded higher in the Mermaid vs. Digitable project $\left(\mathrm{F}_{(1 / 16)}=3.37\right.$, $\mathrm{p}=0.085$ ). Interestingly, no such effects were found for any of the opportunity variables (number of claims and total score). 
The lack of significant effects of the paternity variable on three of the four variables taken into account (number of claims of interest, total hazard scores and total interest scores) suggests that teams of newcomers were able to perform just as well as teams who had generated the creative production themselves. With respect to our $\mathrm{H} 4$ hypothesis, this suggests that the problem of capitalizing creative production concerning future use may be, at least in part, managed by ensuring that allowing a network of multiple groups to exploit the creative production derived from these work sessions. In the section below, we discuss the consequences of this and of our other research findings.

\section{DISCUSSION}

\section{VI.1 USING CPS TO GENERATE SPECULATIVE SCENARIOS OF USE: A QUESTION OF KNOWLEDGE}

Our results raise several questions regarding the use of a creative idea production framework to help designers generate and assess scenarios of future use in the early stages of the innovative design process - particularly in projects where the design brief makes it difficult to identify references in terms of user activity, to generate and validate innovative product concepts.

CPS literature mainly focuses on improving idea fluency. This is based on the assumption that producing many ideas will increase the chances of producing many good ones (Osborn, 1957). This core assumption was demonstrated in the early days of the CPS model (Parnes \& Meadow, 1959), but has been questioned more recently. For example, Rietzschel, Nijstad and Stroebe (2007) note that this argument assumes that "good" ideas are generated randomly, at a constant rate. Instead, they suggest, idea generation depends on the accessibility of knowledge. Knowledge that is most accessible will be activated first, yielding the least original ideas. Knowledge that is less accessible will be activated later in the idea generation task, yielding more original ideas.

Although our experiment did not address originality per se, this hypothesis helps explain our results concerning the effects of CPS methods on fluency. Indeed, each of the two stages of the brainwriting task (generating ideas of potential users and locations of use) required subjects to explore a network comprising "clusters of semantically-related knowledge" (Rietzschel et al., 2007, p. 935). Within the time frame allocated to each of the brainwriting tasks, participants were able to explore this network only partially. The effect of the creative condition on fluency only for ideas related to locations of use, also suggests that information regarding these was less accessible in the native condition, and made more accessible when using CPS methods. Certainly, generating ideas related to locations is not standard practice in scenario-building for UCD. Many authors highlight user characteristics as a more prominent element of this process (e.g. Bardini \& Horvath, 1995; Akrich, 1995). The lack of effect of the condition on the other components of use frames might, then, be 
explained by the fact that the clusters were too easily accessed in either condition for any noticeable difference to emerge within the set time frame. This might also explain why the condition had no significant effect on fluency for scenarios of use: within the allocated time of 20 minutes, no teams were able to completely fill the matrix in the morphological analysis stage. CPS tools may have a more noticeable impact on idea fluency (both for scenarios and for use frame components), if subjects are allowed more time, as these tools allow them to access "clusters of knowledge" which are less easy to activate.

Results concerning the effects of the professional background suggest, from this point of view, that ergonomists' "semantic network" may comprise more knowledge than subjects from other backgrounds. The "semantic network" refers to the internal organization of knowledge. Concepts are organized in Long-Term Memory based on verbal references, but also on a wide array of semantic relationships that define "clusters". For example, the term "games" is semantically related to types of games (e.g. board games, party games, etc.), to specific games (e.g. Monopoly or Cluedo). It follows that exploring a specific use frame may lead to numerous types and levels of knowledge being activated, thereby allowing the construction of numerous scenarios. Verifying this hypothesis, however, would justify a finer analysis of the content of participants' verbal utterances during the experiments. The results presented in this paper suggest that ergonomists are able to extract from this "library", some elements (users, locations, activities) to construct use frames and scenarios of future use.

While this is not standard practice today, ergonomists were able to generate ideas regarding future use in a speculative fashion, during the ideative stages of the innovative design process. Since classical methods of activity analysis may encounter difficulties in the early stages of innovative design, our approach may help ergonomists contribute better to the "fuzzy front-end of innovation". Certainly, their superior fluency may help them generate more numerous and diverse scenarios of future use. However, it should be pointed out that ergonomists did not generate significantly more ideas than other professions in the claims analysis stage (stage 2). In the early stages of the process, just as many claims were generated, on average, by the various types of design professionals. But formulating explicit claims is likely to help ergonomists negotiate the investigation of those claims later on in the project, and influence innovation at the "fuzzy front-end".

More research should be carried out to understand their superior fluency in generating frames and scenarios for future use. In addition to Daniellou's concept of "situation library", which highlights cognitive factors, research on group idea generation suggests that social factors may also be involved (Paulus, 2000). The superior fluency of ergonomists might, then, also be due to the fact that participants from other backgrounds felt less legitimate to discuss future use. This raises questions regarding the relevance and feasibility of equity in idea generation as far as future use is concerned. It questions the position that ergonomists should take in design projects where user activity is initially undefined or ill-defined, and how they might best contribute to define it. This research should also integrate criteria other than fluency, e.g. originality and elaboration, to characterize how ergonomists' strategies in 
exploring future use may prove more efficient than those of other professions of design. Our current work focuses on these issues.

\section{VI.2 CPS AS A "MAGIC BULLET" FOR SCENARIO-BASED DESIGN AT THE FUZZY FRONT-END OF INNOVATION?}

Relying on a CPS framework for prospective ergonomics rests on the assumption that design, particularly in its conceptual stages, may be improved by allowing designers to anticipate more scenarios of use. Several authors have pointed out that this is just one approach to ergonomic design (Béguin \& Cerf, 2004; Prost, 2008). Specifically, these authors identify three distinct postures in design professionals: crystallization, which relies on mental models of users and their activity, addressed in this paper; plasticity, which aims to maximize users' "room for manoeuvre" to achieve maximum benefit in use; and development, which focuses on the joint development of users and artefacts. Although crystallization is clearly not enough to fully support all design needs, our results concerning subjective data, as well as the feedback gathered from participants following the experiments, suggest that designers felt a need for structure when exploring future use in the initial stages of design, and that CPS methods provided an easy alternative to open explorations of future use.

However, our results also suggest that the project type variable exerted complex effects on the work of our participants. The Little Mermaid project was viewed as more difficult to work on. Additionally, participants were more fluent on the Digitable project when using CPS, but more fluent on the Mermaid project when freely anticipating future use. This may be explained in two ways.

First, these projects differed depending on what stage of the design process the designers were involved in. Participants viewed identifying innovative applications for an interactive tabletop interface as a more "open" problem, than validating the safety equipment concept. They felt that a static product concept made it difficult to redefine the underlying use frame, even when using CPS. For example, whereas CPS encouraged participants to specify the concept of "children" as users of the necklace in the Little Mermaid project, we were told "a child is a child, there aren't that many ways about it".

A second explanation is that designers might be vulnerable to specific biases due to the nature and outcome of the anticipated scenarios of use. In our work on the Participatory Design process in the Mermaid project, we identified a number of biases whereby users of this product themselves would censor scenarios of future use in which infant users were subject to a hazard (Nelson, Buisine, Aoussat, et al., 2009). For example, future users would brush off some accident scenarios, saying "that would never happen, I never let the kid out of my sight". If designers are subject to the same biases as future users, this suggests they may be acting as reflective users (Bardini \& Horvath, 1995). Therefore, CPS methods fail to fully counter the biases of anticipating future use in such projects. This suggests that creativity tools are, for the time being, not "magic bullets" to comprehensively anticipate future use. But these tools did allow designers to explore other UCD stakes in the project, thinking of the necklace in different terms, as an "interesting" rather than just a "safe" product. 


\section{VI.3 MANAGING USE-CENTRIC CREATIVE PRODUCTION FOR CLAIMS ANALYSIS}

The higher hazard scores in the paternity condition can be viewed as a byproduct of participants' difficulties in questioning the project's use frame and underlying stakes (see section VI.2). With the exception of this result, the paternity variable was found to have no effect on the chosen DVs. This suggests that the creative production from the first cycle in our process model (see Figure 1) could be channelled by several design teams whose job would be to analyse the ideas produced and generate claims for UCD. Using a distributed network of cells dedicated to the discussion of future use at the "fuzzy front-end" of innovation is not just a way to manage this creative production. Claims analysis may benefit greatly from this creative production being subjected to multiple points of view, i.e. those of multiple designers (as in our stage 2), but also those of multiple teams.

\section{CONCLUSION}

This work has examined a method of generation and exploration of scenarios of future use which may allow ergonomists to contribute, within multidisciplinary design teams - and more fluently than other professionals from these teams - to the early stages of the innovation design process. This method likens the generation of use scenarios in the early stages of the innovation design process to an idea generation task based on a design brief. This approximation was useful from an experimental standpoint "in the laboratory", but should also be assessed in a realworld industrial context.

Designers, and in particular ergonomists, were able to generate speculative scenarios of future use by combining ideas in multiple cycles of creative convergence/divergence. But this process would also, no doubt, benefit from gathering knowledge in early stages of design. We agree with Robert and Brangier's (2009) suggestion that this may be achieved by fostering collaborations between ergonomics and other disciplines, e.g. sociology, management science, etc. But at the same time, industrial pressures towards increased efficiency of the design process tend to advocate limiting the expenses of knowledge-gathering. Further work should be carried out in order to define precisely what one means by "optimizing the UCD process" as far as this early user research is concerned.

\section{ACKNOWLEDGEMENTS}

This work was funded by a grant from the French Ministry for Education; Research and Technology. The authors would like to thank all participants for their co-operation. We are also grateful to Marianne Cerf and one anonymous reviewer for their insightful comments, which greatly helped us in revising this paper, and to Christine Esteves, for her contribution. 


\section{REFERENCES}

Adamski, A. J., \& Westrum, R. (2003). Requisite imagination, the fine art of anticipating what might go wrong. In E. Hollnagel (Ed.), Handbook of cognitive task design (pp. 193-220). Aldershot, UK: Ashgate.

Akrich, M. (1995). User representations: Practices, methods and sociology. In A. Rip, T. J. Misa \& J. Schot (Eds.), Managing technology in society. The approach of constructive technology assessment (pp. 167-184). London: Pinter.

Anastassova, M. (2006). L'analyse ergonomique des besoins en amont de la conception de technologies émergente: le cas de la Réalité Augmentée pour la formation à la maintenance automobile. PhD Thesis, Université Paris 5, Paris.

Bandura, A. (1997). Self-efficacy: the exercise of control. New York, NY: W.H. Freeman and Company.

Bandura, A. (2006). Guide for constructing self-efficacy scales. In T. Urdan \& F. Pajares (Eds.), Self-efficacy beliefs in adolescents (pp. 307-337). Greenwich, CT: Information Age Publishing.

Bardini, T., \& Horvath, A. T. (1995). The social construction of the Personal Computer user: the rise and fall of the reflexive user. Journal of communication, 45(3), 40-65.

Béguin, P. (2007a). Innovation et cadre socio-cognitif des interactions concepteursopérateurs: une approche développementale. Le travail humain, 70(4), 369-390.

Béguin, P. (2007b). Taking activity into account during the design process. @ctivités, 4(2), 115-121.

Béguin, P., \& Cerf, M. (2004). Formes et enjeux de l'analyse de l'activité pour la conception des systèmes de travail. @ctivités, 1(1), 54-71.

Boden, M. (2004). The creative mind: myths and mechnisms (2nd ed.). London: Routledge.

Bonnardel, N. (2009). Activités de conception et créativité : de l'analyse des facteurs cognitifs à l'assistance aux activités de conception créatives. Le Travail Humain, 72(1), 5-22.

Boy, G. A. (1997). The group elicitation method for participatory design and usability testing. Interactions, 4(2), 27-33.

Brangier, E., \& Bastien, J. M. C. (2006). L'analyse de l'activité est-elle suffisante et/ou pertinente pour innover dans le domaine des nouvelles technologies? In G. Valléry \& R. Amalberti (Eds.), L'analyse du travail en perspectives: influences et évolutions (pp. 143-156). Toulouse: Octarès.

Brangier, E., \& Robert, J. M. (2010). Manifeste pour l'ergonomie prospective : anticiper de futures activités humaines en vue de concevoir de nouveaux artéfacts. 22ème conférence francophone sur l'interaction homme-machine, Luxembourg : 20-23 Septembre.

Buisine, S. (2010). Quantitative assessment of collaboration. International reports on socio-informatics 7, 32-39. 
Buisine, S., Besacier, G., Aoussat, A., \& Vernier, F. (2012). How do interactive tabletop systems influence collaboration? Computers in human behavior, 28(1), 49-59.

Carroll, J. M. (2000). Making use: scenario-based design of human-computer interaction. Cambridge, MA: MIT Press.

Carroll, J. M., \& Rosson, M. B. (1992). Getting around the task-artifact cycle: how to make claims and design by scenario. ACM Transactions on Information Systems, 10(2), 181-212.

Cropley, D. (2006). In praise of convergent thinking. Creativity Research Journal, 18(3), 391-404.

Daniellou, F. (1985). La modélisation ergonomique de l'activité de travail dans la conception industrielle : le cas des industries de processus continu. $\mathrm{PhD}$ thesis, CNAM, Paris.

Daniellou, F. (1992). Le statut de la pratique et des connaissances dans l'intervention ergonomique de conception (2nd ed.). Bordeaux: Editions du LESC de l'Université Victor Segalen Bordeaux 2.

Daniellou, F. (2004). L'ergonomie dans la conduite de projets de conception de systèmes de travail. In P. Falzon (Ed.), Ergonomie (pp. 359-373). Paris: PUF.

de Dreu, C. K. W., Nijstad, B. A., \& van Knippenberg, D. (2008). Motivated information processing in group judgment and decision making. Personality and social psychology review, 12, 22-49.

de Sá, M., \& Carriço, L. (2008). Defining scenarios for mobile design and evaluation. Proceedings of CHI2008. Florence, Italy: April 5-10.

Hackos, J. T., \& Redish, J. C. (1998). User and task analysis for interface design. New York, NY: Wiley.

Hanington, B. (2003). Methods in the making: a perspective on the state of human research in design. Design issues, 19(4), 9-18.

Hatchuel, A., \& Weil, B. (1999). C-K theory : notions and applications of a unified design theory. Proceedings of the Herbert Simon International Conference on "Design Sciences", Lyon: March 15-16.

Heslin, P. A. (2009). Better than brainstorming ? potential boundary conditions to brainwriting for idea generation in organizations. Journal of Occupational and Organizational Psychology, 82, 129-145.

Howard, T. J., Culley, S. J., \& Dekonick, E. (2008). Describing the creative design process by the integration of engineering design and cognitive psychology literature. Design studies, 29(2), 160-180.

ISO 13407 (1999) Human-centred design processes for interactive systems.

Jeffroy, F. (1987). Maîtrise de l'utilisation d'un système informatique par des utilisateurs non informaticiens. PhD thesis, CNAM, Paris.

Kantrovich, L. (2004). To innovate or not to innovate ? Interactions, 11(1), 24-31.

MacKay, R. B., \& McKiernan, P. (2004). The role of hindsight in foresight: refining strategic reasoning. Futures, 36(2), 161-179.

Maguire, M. (2001). Methods to support human-centered design. International Journal of Human-Computer Studies, 55(4), 587-634. 
Mallard, A. (2005). Following the emergence of unpredictable uses? New stakes and tasks for a social scientific understanding of ICT uses. In L. Haddon (Ed.), Everyday innovators (pp. 39-53). Berlin: Springer.

Nelson, J., Buisine, S., \& Aoussat, A. (2009). Assisting designers in the anticipation of future product use. Asian International Journal of Science and Technology Production and Manufacturing Engineering, 2(3), 24-39.

Nelson, J., Buisine, S., \& Aoussat, A. (2010). Creativity as a tool for prospective use analysis in the design of innovative products. Proceedings of Ergo'IA 2010. Bidart, France: October 13-15.

Nelson, J., Buisine, S., Aoussat, A., \& Duchamp, R. (2009). Elaboration of innovative safety equipment concepts for infants. Proceedings of ICED09. Stanford, CA: August 24-27.

Nijstad, B. A., \& Stroebe, W. (2006). How the group affects the mind: a cognitive model of idea generation in groups. Personality and social psychology review, 10(3), 186-213.

Osborn, A. F. (1957). Applied Imagination. New York, NY: Scribner.

Oulasvirta, A., Kurvinen, E., \& Kankainen, T. (2003). Understanding contexts by being there: case studies in bodystorming. Personal and ubiquitous computing, $7(2), 125-134$.

Parnes, S. J., \& Meadow, A. (1959). Effects of "brainstorming" instructions on creative problem solving by trained and untrained subjects. Journal of educational psychology, 50(4), 171-176.

Paulus, P. B. (2000). Groups, teams and creativity: the creative potential of ideagenerating groups. Applied psychology, 49(2), 237-262.

Paulus, P. B., \& Yang, H. C. (2000). Idea generation in groups: a basis for creativity in organizations. Organizational behavior and human decision processes, 82(1), 76-87.

Plucker, J. A., \& Makel, M. C. (2010). Assessment of creativity. In J. C. Kaufman \& R. J. Sternberg (Eds.), The Cambridge Handbook of Creativity (pp. 48-73). Cambridge, UK: Cambridge University Press.

Prost, L. (2008). Modéliser en agronomie et concevoir des outils en interaction avec de futurs utilisateurs : le cas de la modélisation des interactions génotypeenvironnement et de l'outil DIAGVAR. PhD thesis, AgroParisTech, Paris.

Redström, J. (2006). Towards user design ? On the shift from object to user as the subject of design. Design Studies, 27(2), 123-129.

Reid, S.E., \& de Brentani, U. (2004). The fuzzy front-end of new product development for discontinuous innovations: a theoretical model. Journal of product innovation management, 21(3), 170-184.

Rietzschel, E. F., Nijstad, B. A., \& Stroebe, W. (2007). Relative accessibility of domain knowledge and creativity: The effects of knowledge activation on the quantity and originality of generated ideas. Journal of experimental social psychology, 43(6), 933-946. 
Robert, J. M., \& Brangier, E. (2009). What is prospective ergonomics? A reflection and a position on the future of ergonomics Paper presented at the HCI international conference 2009. San Diego, CA: 19-24 July.

Rosson, M. B., \& Carroll, J. M. (2002). Usability engineering: scenario-based development of human-computer interaction. San Diego, CA: Academic Press.

Schumpeter, J.A. (1934). The theory of economic development. Boston, MA: Harvard University Press.

Stroebe, W., Nijstad, B. A., \& Rietzschel, E. F. (2010). Beyond productivity loss in brainstorming groups: the evolution of a question. Advances in experimental social psychology, 43, 157-203.

Theureau, J., \& Pinsky, L. (1984). Paradoxe de l'ergonomie de conception et logiciel informatique. Revue des conditions de travail 9, 25-31.

Valentin, A., Lancry, A., \& Lemarchand, C. (2010). La construction des échantillons dans la conception ergonomique de produits logiciels pour le grand public : quel quantitatif pour les études qualitatives ? Le Travail Humain, 73(3), 261290.

Veryzer, R. M., \& Borja de Mozota, B. (2005). The impact of user-oriented design on New Product Development: an examination of fundamental relationships. Journal of product innovation management, 22(2), 128-143.

Vinck, D. (2009). De l'objet intermédiaire à l'objet-frontière : vers la prise en compte du travail d'équipement. Revue d'anthropologie des connaissances, 3(1), 51-72.

Visser, W. (2009). La conception : de la résolution de problèmes à la conception de représentations. Le Travail Humain, 72(1), 61-78.

Voros, J. (2009). Morphological prospection : profiling the shapes of things to come. Foresight, 11(6), 4-20.

Zeng, L., Proctor, R. W., \& Salvendy, G. (2010). Creativity in Ergonomic Design: A Supplemental Value-Adding Source for Product and Service Development. Human Factors, 52(4), 503-525.

\section{RÉSUMÉ EN ANGLAIS}

This paper presents a methodological contribution to ergonomics in the early stages of innovative design projects, focused on the anticipation of future needs and activities. We examined the effect, on designer activity during simulated design meetings, of a toolset using tools from Creative Problem Solving and reliability engineering, on ideation related to future uses of a product. Multidisciplinary design teams generated scenarios of future use based on the design brief of two innovative products with ill-defined uses: an interactive tabletop interface, and an innovative device to prevent drowning in infants. They worked either in an open fashion, or using brainwriting and morphological analysis to generate ideas related to elements of future use, and combine them together into scenarios. The scenarios were then subjected to claims analysis, using a modified version of the FMECA method. Analysing oral and written traces of designer activity, we measured the fluency of ideas concerning scenario components, complete scenarios, and positive or negative 
claims derived from these scenarios. Using a questionnaire, we assessed participants' perceptions of self-efficacy in these work situations. Results show that these tools were viewed as an easier alternative to open exploration of future use from the design brief. Design teams were, within identified limits, able to formulate propositions regarding possible scenarios of future use, and to generate positive and negative claims regarding these scenarios to guide future design projects. Results show the superior ability of ergonomists to produce ideas regarding some elements of future use, as well as scenarios of future use, in the context of defining future use in the early stages of innovation projects.

Keywords: Innovative design, scenario-based design, product design, prospective ergonomics, creativity 